\title{
A Fascinating Example for Convergent Evolution: Endangered Vultures
}

\section{Michael O'Neal Campbell*}

Environmental Scientist, Lakehead University, Ontario, Canada

"Corresponding author: Michael O'Neal Campbell, Environmental Scientist, Lakehead University, Ontario, Canada, Tel: 2502203434; E-mail: ecol55@hotmail.com

Rec date: April 29, 2014; Acc date: June 12, 2014; Pub date: June 21, 2014

Copyright: (c) 2014 Campbell MO. This is an open-access article distributed under the terms of the Creative Commons Attribution License, which permits unrestricted use, distribution, and reproduction in any medium, provided the original author and source are credited.

\begin{abstract}
Convergent evolution, an extremely important topic within biodiversity studies, refers to the independent development of similar features in the descendants of different ancestral groups. The variably derived descendants may be similar, depending on the analogues or similar features. New and Old World vultures are an interesting example of convergent evolution. They have similar ecological roles, food habits and features and like the hawks and owls, may have evolved from different species. This convergence may be due to similar ecological conditions that may result in similar trajectories in different species, genera, families or even Orders.
\end{abstract}

Keywords: Convergent evolution; Endangered Vultures; Evolution

\section{Introduction}

To introduce convergent evolution, we must first distinguish it from other forms of evolution that are also relevant to biodiversity. Convergent evolution is different from parallel evolution. In the convergent evolution of two or more descendant species, genera or families, the ancestral groups are different, while in parallel evolution the ancestral groups are similar. In reality however, it may be difficult to distinguish convergent evolution from parallel evolution, as the ancestral groups may not be definitively known. This is important, because if different ancestral groups can evolve similar ecological roles, they may make similar contributions to biodiversity and may react similarly to factors that may enhance, maintain or endanger their existence [1].

\section{Convergent Vulture Evolution}

The New World or Cathartid Vultures (Family Cathartidae, found in North and South America, termed the New World) and Old World or Accipitrid Vultures (Family Accipitridae, found in Africa, Europe and Asia, termed the Old World) are an important example of convergent evolution; contemporary evidence and sometimes polarized opinion points to different ancestral groups [2,3]. In the past, vultures were once thought to have evolved "only once among extant diurnal birds of prey" [4]. Now New World Vultures are classified as ancestrally related, or near to the storks [5]. Old World Vultures are more definitively linked to raptors or bird (Or) prey ancestors [6].

The issue of vulture evolution, indeed of vulture existence, has recently caught global attention, largely due to the diclofenac debacle in India and Pakistan at the beginning of the 21st century, where the veterinary drug diclofenac used for cattle health was found to be almost instantly fatal to vultures that fed on cattle carcasses (the main vulture food source in South Asia) [7]. This ban on diclofenac production for vetinary use reduced some of the world's commonest birds of prey, such as the Indian Vulture, Slender-billed Vulture and the White-rumped Vulture to endangered species near extinction [8]. Other smaller events were the reintroduction of the California Condor into the wild from a captive breeding program[9] and the increased problems with populations of Turkey and Black Vultures in American cities[10,11]. Searching questions also emerged, as to whether vultures are relics from past periods, when vast herds of huge mammals provided the abundant, easy food for huge vultures, which are now unsuited to the modern world of garbage, road kills and sanitation management [12].

The analogus features that define vultures, shared by both the Cathartid and Accipitrid Vultures, have also been increasingly scrutinized. These features are:

- Bald or partially bald heads for cleanliness or thermoregulation;

- Long broad wings for soaring flight in thermals and orographic lift;

- Sharp eyesight for foraging from high altitudes;

- Strong stomach acids for digestion of rotting, diseased meat;

- Long intestines;

- Nests in elevated trees or cliff crevices (to protect against ground carnivores and facilate takeoffs for large, heavy birds);

- Relatively weak feet for walking rather than for grasping;

- Bills designed for tearing meat (in the largest species),

Pulling meat (in the large to medium sized Griffon Vulture species) and for picking small meat morsels (in the smallest species). The largest Cathartids are the Andean and California Condors, while the largest Accipitrid Vultures are the condor-sized Cinereous Vulture (which has a tearing bill) and the Himalyan Griffon Vulture; the latter like the related smaller Griffon Vultures has a bill for pulling meat. The smaller species, i.e. the Black and Turkey Vultures in the New World and the Egyptian and Hooded Vultures in the Old World have the small, slender bills for pecking small morsels $[13,14]$.

\section{Differences between new world and old world vultures}

Physical and behavioural features that distinguish New World Vultures from the Old World Vultures include;

- A sense of smell in the Genus Cathartes (the Turkey Vulture, Yellow-headed and Greater Yellow-headed Vultures)

- Longer slightly webbed front toes 
- Weaker feet

- The lack of a syrinx or voice box

- Oval perforate nostrils with no dividing septum (the nostrils appear as a hole through the head behind the bill)

- The lack of a bony brow over the eyes (these make the Old World Vultures appear as if they are frowning)

- The habitat of defecating on the legs for cooling purposes (shared with the storks) [15]

Observers and researchers in past centuries sensed differences between the New and Old World Vultures and studied these with relatively primitive morphological studies; i.e. examination of skeletons, bills, feet and feathers [5,16,17]. More recent studies used karayological (chromosome based) tools and also Deoxyribonucleic acid (DNA). DNA is a molecule that contains the codes of the genetic instructions for the development, maintenance and functioning of living organisms. Some of these methods used the nucleotide sequence of the mitochondrial cytochrome b (cyt b), which can contain records phylogenetic events or evolutionary changes in organisms within the last 20 million years. The results of these more advanced studies indicate that vultures are polyphyletic; i.e. they are descended from several different ancestral groups. They were found to comprise at least three monophyletic groups; each of these three groups having a common ancestor or ancestral group [6].

The Old World Vultures have been seen as either a monophyletic or polyphetic group [18]. In the latter case the Egyptian, Bearded and Palm-nut Vultures would be one group in the subfamily Gypaetinae. The rest of the Old World Vultures, including the seven species of downy-headed Griffons of the genus Gyps, and the other large vultures with the small Hooded Vultures would be in the subfamily Aegypiinae. The two subfamilies would have different ancestral groups. Regarding ancestors and relatives, there are disputes on the relation of particular vulture species to other raptors. A few researchers have argued that the feather - headed Bearded Vulture and Palm-nut Vulture are not fully vultures, and that the White-headed Vulture is actually between the vultures and eagles [19].

The New World Vultures are generally seen as monophyletic; however opinions and experimental results differ on just how closely related they are to storks or birds of prey. The majority of DNA based studies have found a close link with storks [20]. Some have gone so far is to include them entirely as a subfamily of storks [21]. Other studies have found that they are not closely related to either storks or birds of prey [22]. With the exception of the Genus Cathartes (containing the Turkey Vulture, Yellow-headed and Greater-Yellow-headed Vulture), New World Vultures (Andean Condor, California Condor, King Vulture, Black Vulture) are each placed in a separate, single species genus [23]. Nevertheless, their generally monphyletic status hints at a common ancestral group and few studies have conclusively linked some New World Vultures as closer than others to storks (although the King Vulture was morphologically described as closer to the birds of prey than the other Cathartids, due to its larger, stronger hooked beak) [14].

\section{Conclusion}

The research in this field is ongoing, and no final conclusions have been reached. From the perspective of biodiversity and endangered species, such convergent evolution is particularly important, as vultures are the only obligate or permanent scavengers in ecosystems [24]. Other species such as storks, eagles, sea gulls and even mammals such as hyenas and jackals are facultative or temporary scavengers [25]. For different ancestral groups to evolve different types of vultures underscores the ecological importance of long range, large, numerous, keen eyed obligate scavengers. Unfortunately, some of these species are now counted among the endangered, and those ecosystems that benefited from their services must now rely on the less efficient facultative species, resulting in increased occurrences of unconsumed carrion and diseases. Other vulture species are encountering a cleaner world that no longer needs the birds that once fed on dead prehistoric mega fauna. Whether research and policy will solve the 'vulture crisis' and understand more fully the role of vultures in the modern world remains to be seen.

\section{References}

1. McGhee GR (2011) Convergent Evolution: Limted Forms Most Beautiful. MIT Press, Cambridge.

2. Bird DM (1996) Raptors in Human Landscapes: Adaptation to Built and Cultivated Environments. Academic Press, Salt Lake City.

3. Del Hoyo J, Elliott A, Sargatal J (1994) Handbook of birds of the world. Vol 2. New World vultures to guineafowl. Lynx Edicions, Barcelona, Spain.

4. Seibold I, Helbig AJ (1995) Evolutionary History of New and Old World Vultures Inferred from Nucleotide Sequences of the Mitochondrial Cytochrome b Gene. Philosophical Transactions of the Royal Society B: Biological Sciences 350: 163-178.

5. Rea AM (1983) Cathartid affinities: a brief overview. In Wilbur, S.R. and Jackson, J.A. (eds.) Vulture Biology and Management, 26-54. University of California, Berkeley.

6. Wink M (1995) Phylogeny of Old and New World vultures (Aves: Accipitridae and Cathartidae) inferred from nucleotide sequences of the mitochondrial cytochrome $\mathrm{b}$ gene. Verlag der Zeitschrift für Naturforschung 50: 868-882.

7. Oaks J, Gilbert M, Virani MZ, Watson RT, Meteyer CU (2004) Diclofenac residues as the cause of vulture population decline in Pakistan. Nature 427: 630-633.

8. Prakash V, Green RE, Pain DE, Ranade SP, Saravanan, S (2007) Recent changes in populations of resident Gyps vultures in India. Journal of the Bombay Natural History Society 104: 129-135.

9. Hunt W, Parish C, Farry S, Lord T, Sieg, R (2007) Movements of introduced California condors in Arizona in relation to lead exposure. California condors in the 21st century. Series in Ornithology No. 2., 7996. Nuttall Ornithological Club and American Ornithologists' Union, Cambridge, MA.

10. Novaes WG, Cintra R (2013) Factors influencing the selection of communal roost sites by the Black Vulture Coragyps atratus (Aves: Cathartidae) in an urban area in Central Amazon. ZOOLOGIA

11. Blackwell BF, Avery ML, Watts BD, Lowney MS (2007) Demographics of Black Vultures in North Carolina. USDA National Wildlife Research Center - Staff Publications.

12. Nielsen J (2006) Condor: To the Brink and Back-The Life and Times of One Giant Bird. Harper Perennial, New York.

13. Konig C (1983) Interspecific and intraspecific composition for food among Old World vultures. In Wilbur, S.R. and Jackson, J.A. (eds.) Vulture Biology and Management, $153-171$.

14. Fisher HI (1944) The skulls of the Cathartid vultures. Condor 46: 272-296.

15. Ferguson-Lees J, Christie DA (2001) Raptors of the World. Christopher Helm, London.

16. Garrod AH (1873) On certain muscles in the thigh of birds and their value for classification. Proceedings of the Zoological Society of London 1873: 626-644.

17. Sibley SG, Ahlquist JE (1990b) Phylogeny and Classification of Birds. A Study in Molecular Evolution. Yale University Press, Yale, New Haven. 
Citation: Campbell MO (2014) A Fascinating Example for Convergent Evolution: Endangered Vultures. J Biodivers Endanger Species 2: 132. doi:10.4172/2332-2543.1000132

Page 3 of 3

18. Mundy P, Butchard D, Ledger J, Piper S (1992) The Vultures of Africa Academic Press, New York, USA.

19. Wink M, Sauer-Gürth H (2004) Phylogenetic relationships in diurnal raptors based on nucleotide sequences of mitochondrial and nuclear marker genes. In Chancellor, R.D and Meyburg, B.-U. (eds.) Raptors Worldwide, 483-498. WWGBP/Hancock House, Mérida and Berlin.

20. Fain MG, Houde P (2004) Parallel radiations in the primary clades of birds. Evolution 58: 2558-2573.

21. Sibley CG, Monroe BL (1990) Distribution and Taxonomy of Birds of the World. Yale University Press, New Haven, London.
22. Ericson PGP, Anderson CL, Britton T, Elżanowski A, Johansson US (2006) Diversification of Neoaves: integration of molecular sequence data and fossils. Biology Letters 22; 2: 543-547.

23. Myers P, Espinosa R, Parr CS, Jones T, Hammond GS (2008) Family Cathartidae University of Michigan Animal Diversity Web

24. Ruxton GD, Houston DC (2004) Obligate vertebrate scavengers must be large soaring fliers. Journal of Theoretical Biology 228: 431-436.

25. Ogada DL, Torchin ME, Kinnaird MF, Ezenwa VO (2012) Effects of vulture declines on facultative scavengers and potential implications for mammalian disease transmission. Conservation Biology 26: 453-460. 